\title{
Fertigation and growing media for production of anthurium cut flower
}

\author{
Francine Lorena Cuquel ${ }^{1}$; Simone W Polack ${ }^{2}$; Nerilde Favaretto ${ }^{1}$; João Carlos Possamai ${ }^{1}$ \\ ${ }^{1}$ UFPR, R dos Funcionários 1540, 80035-050 Curitiba-PR; ${ }^{2}$ Secretaria de Estado de Agricultura e Abastecimento, R dos Funcionários \\ 1559, 80035-050 Curitiba-PR; francine@ufpr.br
}

\begin{abstract}
Anthurium andraeanum flowers quality and productivity depend on the fertilizer, and the growing media used. Most Brazilian anthurium growers use to prepare their growing media, but they do not realize that the low quality and productivity might come from an inadequate mix that they are using. So, the objective was to determine yield and flower quality of anthurium plants grown in different growing media and fertilizations. 'Eidibel' anthurium plants were grown in: a) pine bark + composted organic matter $(1: 1)$; b) wood shavings + composted organic matter $(1: 1)$; c) growing media usually utilized by the grower where this study was developed (a mixture of soil, coal residue and composted cow manure). Four fertigation solutions were applied weekly during eleven months. These solutions were: NPK 100\% (5.00: 1.64: 3.12 g plant $^{-1}$ year $^{-1}$ ); $\mathrm{N}$ and K 100\% + P 150\% (5.00: 2.46: 3.12 g plant $^{-1}$ year $\left.^{-1}\right)$; N and P 100\% + K 150\% (5.00: 1.64: 4.70 g plant $^{-1}$ year $\left.^{-1}\right) ; \mathrm{N} \mathrm{100 \%} \mathrm{+} \mathrm{P} \mathrm{and}$ $\mathrm{K}$ 150\% (5.00: 2.46: 4.70 g plant $^{-1}$ year $\left.^{-1}\right)$. These were compared with monthly fertilization done locally with slow releasing solid fertilizer (4.52: 1.23: $4.99 \mathrm{~g} \mathrm{plant}^{-1}$ year $^{-1}$ ). Although there was no increase in the yield, represented by the number of flowers produced per plant, the growing media prepared with wood shavings + organic compost $(1: 1)$ with all fertilization tested produced the best quality anthurium cut flowers (Extra and Class I).
\end{abstract}

Keywords: Anthurium andraeanum, floriculture, ornamental plant, substrate.

\section{RESUMO}

Fertirrigação e subtrato para a produção de flores de antúrio

Qualidade das flores e a produtividade de antúrio (Anthurium andraeanum) dependem da adubação e do substrato utilizados. A maioria dos produtores brasileiros de antúrio costuma preparar seu substrato, mas eles não imaginam que o uso de substratos inadequados pode ser a causa de seus problemas de baixa qualidade ou baixa produtividade. $\mathrm{O}$ objetivo deste estudo foi avaliar a produtividade e qualidade de flores de antúrio cultivado em diferentes substratos e adubações. Plantas de antúrio da cultivar Eidibel foram plantadas em: a) casca de pinus + matéria orgânica decomposta (1:1); b) mistura de maravalha e composto (1:1); c) mistura de solo com resíduo de carvoaria e esterco de gado decomposto (substrato utilizado pelo produtor onde a pesquisa foi desenvolvida). Quatro fertirrigações foram aplicadas semanalmente durante onze meses. Estas soluções eram: NPK 100\% (5,00:1,64:3,12 g planta $^{-1}$ ano $\left.^{-1}\right)$; $\mathrm{N}$ e K $100 \%$ + P 150\% (5,00:2,46:3,12 g planta $\left.^{-1} \mathrm{ano}^{-1}\right)$; N e P $100 \%$ + K 150\% (5,00:1,64:4,70 g planta ${ }^{-1}$ ano $\left.^{-1}\right)$; N 100\% + P e K 150\% $\left(5,00: 2,46: 4,70\right.$ g planta $^{-1}$ ano $\left.^{-1}\right)$. Estas soluções foram comparadas com a adubação feita pelo produtor local com adubo sólido de liberação lenta (4,52:1,23:4,99 g planta $^{-1}$ ano $\left.^{-1}\right)$. Embora não haja ocorrido aumento da produtividade, representada pelo número de flores por planta, o substrato preparado com maravalha + composto (1:1) com todas as adubações testadas produziu as melhores flores de antúrio (Extra e Classe I)

Palavras-chave: Anthurium andraeanum, floricultura, planta ornamental, substrato.

(Recebido para publicação em 12 de maio de 2011; aceito em 18 de maio de 2012) (Received on May 12, 2011; accepted on may 18, 2012)

\begin{abstract}
$\mathrm{A}$ nthurium (Anthurium andraeanum) is on of the most commercialized cut flowers in the world (CBI Market Information Database, 2007). Additionally, it is the main ornamental plant grown in the Ribeira Valley (São Paulo, Brazil), estimated that there are 1.7 million plants in the region (Tombolato et al., 2002).

The commercial yield of anthurium varies from 4 to 9 floral stems per plant per year (Cuquel \& Grossi, 2004; Talia et al., 2003; Singh et al., 2011). Anthurium nutritional status affects yield, quality (Cuquel \& Grossi, 2004; Sakai, 2004; Dufour \& Guérin, 2005), and susceptibility to bacterial (Pfleger $\&$ Gould, 2009), and fungal diseases
\end{abstract}

(Deshmukh \& Mehetrep, 2010). The suitable choice of growing media and fertilizers is indispensable (CaldariJunior, 2004). Most Brazilian anthurium growers use to prepare their growing media, but they do not realize that their low quality and productivity might came from an inadequate mix that they are using. Hence, it is essential to have a good knowledge of the plant's mineral requirements in order to avoid nutrient waste. The matching of supply and demand may decrease production costs and reduce the risk of water pollution (Dufour \& Guérin, 2005). On the other hand, it is necessary to limit mineral imbalance in the medium by assuring a minimal leaching of excess nutrient solution (Chang et al., 2010).

Nitrogen deficiency in anthurium can diminish yield and flower quality, besides it increases the juvenile period (Tombolato et al., 2002; Dufour \& Guérin, 2005). Roots damage and secondary infection by fungi and bacteria are also associated with nitrogen deficiency (Henny, 1999; Pfleger \& Gould, 2009; Deshmukh \& Mehetrep, 2010). Phosphorus deficiency in anthurium results in atrophic plants, with small, dark-green and narrow leaves, with short petioles; old leaves are chlorotic, with necrotic areas along the margins also affecting the root system (Tombolato et al., 2002). The supply of potassium directly affects the plant 
development by controlling absorption and evaporation of water (Tombolato et al., 2002). It plays an essential role in yield and flower quality (Tombolato et al., 2002). Potassium deficiency diminishes the length of the floral stem (Dufour \& Guérin, 2005) and the red and orange spathes can show bluish points or areas (Tombolato et al., 2002).

In the commercial production of anthurium every year the growing media must be topped up (Umaharan \& Elibox, 2011). It is recommended that growing media should be well aerated (CaldariJunior, 2004), with good porosity (Sakai, 2004), with good drainage, but with the ability to retain sufficient moisture, and provide support to the plant (Sakai, 2004; Umaharan \& Elibox, 2011). The growing media should have electrical conductivity between 0.5 and $1.5 \mathrm{dS}$ $\mathrm{cm}^{-1}$ (Tombolato et al., 2002; Dufour \& Guérin, 2003; Talia et al., 2003; CaldariJunior, 2004), and pH between 4.5 and 6.5 (Minami \& Salvador, 2010; Talia et al., 2003; Dufour \& Guérin, 2003). Other important considerations of growing media include availability, cost, and ease of handling (Higaki \& Poole, 1978; Umaharan \& Elibox, 2011). The properties of the growing media depend on the materials employed in its preparation, which in general, have prior soluble salts inherent to its material, even before fertilizing (Minami \& Salvador, 2010). Various locally available raw material have been utilized to prepare growing media for commercial production of anthurium, especially fresh or composted pine bark (Stancato \& Silveira, 2010); forest litter, sugarcane bagasse, wood chips, coconut fiber, superficial layer of forest areas, leaf humus (Henny, 1999); sand, and coir dust (Umaharan \& Elibox, 2011); mixture of rough sand, composted cow manure (1:1:1) (Loges et al., 2004).

This research was implemented with the aim of determine yield and flower quality of anthurium plants grown in different growing media and fertilizations.

\section{MATERIAL AND METHODS}

This study was carried out in the coast of Paraná state, Brazil (259'S,
489"W, 52 m above sea level). The monthly rainfall is $292 \mathrm{~mm}$, the maximum temperature is $41.2^{\circ} \mathrm{C}$ and minimum is $7.5^{\circ} \mathrm{C}$ (Cuquel \& Grossi, 2004). This experiment was performed in a greenhouse covered with Blue Cromatinet ${ }^{\mathrm{TM}}$ fabric without control of rain and temperature. The crop management during the whole production cycle, except for growing media and fertilization utilized, was that usually applied by the grower. Seedlings of anthurium cv. Eidibel, propagated by cutting, showing a mean height of $74 \mathrm{~cm}$, were planted in $20 \mathrm{~cm}$ elevated beds above the ground spaced with 25 $\mathrm{cm}$ between plants and $30 \mathrm{~cm}$ between rows (13.33 plants $\mathrm{m}^{-2}$ ).

The materials selected for preparing the growing media were those with low cost available in the region, which showed a slow rate of decomposition and small granulometry: pine bark (mean particle diameter of 1 to $2.5 \mathrm{~cm}$ ), partially composted wood shavings (sawmill byproduct), and composted organic matter (from the decomposition of plant residues and cow manure for 90 days in the open). Its physical-chemical characteristics are showed on the Table 1. Three growing media were prepared using local available materials. They were S1) pine bark and organic matter in a volume proportion of $1: 1 ; \mathrm{S} 2$ ) wood shavings and composted organic matter in a volume proportion of of $1: 1 ;$ S3) the growing media usually utilized by the grower and made by mixing $1 \mathrm{~m}^{3}$ of soil, 123 L of charcoal (obtained from wood carbonization), $0.19 \mathrm{~m}^{3}$ of composted cow manure, $0.75 \mathrm{~kg}$ of limestone and $1.7 \mathrm{~kg}$ of granulated fertilizer 4:14:8. Its physical characteristics are shown on the Table 2. Raw materials and growing media physical analyses were performed as Fermino (2003), and chemical analyses were performed as recommended by Horwitz \& LatimerJunior (2011).

The nutritive fertigation solutions (A1 to A4) (Table 3) were prepared with commercial soluble salts: ammonium monophosphate, potassium nitrate, magnesium sulfate, ammonium sulfate, ammonium nitrate and calcium chloride. During 11 months an amount of 700 $\mathrm{mL}$ of nutritive solution was weekly applied in each plant, totaling 35.7 L of nutritive solution per plant. During this study period rainfall was sufficient for the development of the culture, with a monthly average of $339.21 \mathrm{~mm}$, and was not necessary to do supplementary plant irrigation. The concentrations of nutrients in the solutions were based on recommendations for anthurium. The solution A1 was prepared based on the recommendation for phosphorus and potassium for anthurium flowers, determined by Matthes et al. (1997).

Table 1. Physical-chemical characteristics of the materials utilized to prepare the growing media for cultivation of $A$. andraeanum (caracteristicas físico-químicas dos materiais usados no preparo do meio de cultura para cultivo de A. andraeanum). Guaratuba, UFPR, 2004-2005.

\begin{tabular}{|c|c|c|c|}
\hline Characteristics/materials $^{1}$ & Pine bark & Organic matter & Wood shavings \\
\hline Dry density $\left(\mathrm{kg} \mathrm{m}^{-3}\right)$ & 160.00 & 138.00 & 129.00 \\
\hline Total porosity $\left(\mathrm{m}^{3} \mathrm{~m}^{-3}\right)$ & 98.00 & 0.86 & 0.42 \\
\hline Aeration space $(\%)$ & 0.38 & 0.48 & 0.25 \\
\hline Easily available water (\%) & 0.11 & 0.13 & 0.00 \\
\hline Available water (\%) & 0.15 & 0.14 & 0.00 \\
\hline $\mathrm{pH}$ & 4.60 & 6.30 & 3.90 \\
\hline $\mathrm{EC}\left(\mathrm{dS} \mathrm{cm} \mathrm{cm}^{-1}\right)$ & 0.10 & 1.30 & 0.10 \\
\hline Nitrogen (nitrate) $\left(\mathrm{mg} \mathrm{L}^{-1}\right)$ & 0.70 & 121.00 & 0.40 \\
\hline Nitrogen (ammonia) $\left(\mathrm{mg} \mathrm{L}^{-1}\right)$ & 0.70 & 1.40 & 0.40 \\
\hline Phosphorus (mg L-1) & 2.50 & 74.90 & 0.04 \\
\hline Potassium (mg L'-1) & 11.70 & 48.50 & 0.80 \\
\hline
\end{tabular}

${ }^{1}$ Physical analysis was performed as Fermino (2003) and chemical analysis was performed as Horwitz \& Latimer-Junior (2011) (análise física conforme Fermino (2003) e química conforme Horwitz \& Latimer-Junior (2011)). 
Table 2. Physical-chemical characteristics of growing media utilized for growing $A$. andraeanum (caracteristicas físico-químicas dos meios de crescimento usados no cultivo de A. andraeanum). Guaratuba, UFPR, 2004-2005.

\begin{tabular}{|c|c|c|c|c|c|c|}
\hline \multirow[t]{2}{*}{ Characteristic $^{1}$} & \multicolumn{2}{|c|}{$\begin{array}{c}\text { Pine bark + organic } \\
\text { matter }(1: 1)\end{array}$} & \multicolumn{2}{|c|}{$\begin{array}{c}\text { Wood shavings }+ \text { organic } \\
\text { matter }(1: 1)\end{array}$} & \multicolumn{2}{|c|}{ Grower $^{2}$} \\
\hline & Initial $^{3}$ & Final $^{4}$ & Initial $^{3}$ & Final $^{4}$ & Initial $^{3}$ & Final $^{4}$ \\
\hline Dry density $\left(\mathrm{kg} \mathrm{m}^{-3}\right)$ & 154.0 & 584.0 & 169.0 & 683.0 & 731.0 & 775.0 \\
\hline Total porosity (\%) & 82.0 & 79.0 & 91.0 & 77.0 & 78.0 & 73.0 \\
\hline Solids (\%) & 18.0 & 21.0 & 9.0 & 23.0 & 22.0 & 27.0 \\
\hline Aeration space $(\%)$ & 40.0 & 24.0 & 28.0 & 21.0 & 28.0 & 24.0 \\
\hline Moisture (\%) & 42.0 & 55.0 & 63.0 & 56.0 & 50.0 & 49.0 \\
\hline Easily available water (\%) & 6.0 & 12.0 & 16.0 & 13.0 & 14.0 & 13.0 \\
\hline Buffering capacity (\%) & 8.0 & 15.0 & 19.0 & 16.0 & 17.0 & 16.0 \\
\hline Remaining water (\%) & 28.0 & 28.0 & 28.0 & 27.0 & 19.0 & 20.0 \\
\hline $\mathrm{pH}$ & 5.6 & 5.9 & 6.2 & 6.2 & 6.8 & 4.7 \\
\hline $\mathrm{EC}\left(\mathrm{dS} \mathrm{cm} \mathrm{cm}^{-1}\right)$ & 0.8 & 0.2 & 0.2 & 0.2 & 0.3 & 0.2 \\
\hline CTC & 119.9 & 5.6 & 83.9 & 6.2 & 75.9 & 6.8 \\
\hline Nitrogen (nitrate) (mg L-1) & 6.9 & 10.1 & 0.7 & 9.9 & 24.2 & 8.2 \\
\hline Nitrogen (ammonia) (mg L-1) & 2.6 & 1.2 & 0.7 & 1.0 & 2.0 & 1.7 \\
\hline Phosphorus (mg L-1) & 79.6 & 2.5 & 46.6 & 1.5 & 0.03 & 0.6 \\
\hline Potassium (mg L-1) & 42.8 & 8.3 & 3.4 & 7.2 & 17.6 & 7.0 \\
\hline
\end{tabular}

${ }^{1}$ Physical analysis was performed as Fermino (2003) and chemical analysis was performed as Horwitz \& Latimer-Junior (2011) (análise física conforme Fermino (2003), análise química conforme Horwitz \& Latimer-Junior (2011)); ${ }^{2}$ Grower media was prepared with a mixture of 1 $\mathrm{m}^{3}$ of soil, $123 \mathrm{~L}$ of charcoal, $0.19 \mathrm{~m}^{3}$ of composted cow manure, $0.75 \mathrm{~kg}$ of lime and $1.7 \mathrm{~kg}$ of solid fertilizer 4-14-8 (substrato do produtor preparado com mistura de $1 \mathrm{~m}^{3}$ de solo, $123 \mathrm{~L}$ de carvão, $0,19 \mathrm{~m}^{3}$ esterco bovino composto, $0,75 \mathrm{~kg}$ de calcário e $1,7 \mathrm{~kg}$ de fertilizante sólido 4-14-8); ${ }^{3}$ Sample obtained at beginning of study (amostra obtida no início do estudo) ; ${ }^{4}$ Sample obtained 12 months after planting, from the region of greatest concentration of roots (amostra obtida aos 12 meses do plantio, de região com maior concentração de raizes).

Table 3. Growing media and fertilizations utilized for cultivation of $A$. andraeanum (meios de crescimento e fertilizações utilizadas no cultivo de A. andraeanum). Guaratuba, UFPR, 2004-2005.

\begin{tabular}{|c|c|c|c|c|}
\hline \multirow{2}{*}{ Growing media } & \multirow{2}{*}{ Fertilization } & $\mathbf{N}$ & $\mathbf{P}$ & $\mathbf{K}$ \\
\hline & & \multicolumn{3}{|c|}{ (g/plant/year) } \\
\hline Pine bark + organic matter $(1: 1)$ & $\mathrm{A} 1=\mathrm{NPK}(100 \%)$ & 5.00 & 1.64 & 3.12 \\
\hline Wood shavings + organic matter $(1: 1)$ & $\mathrm{A} 1=\mathrm{NPK}(100 \%)$ & 5.00 & 1.64 & 3.12 \\
\hline Grower $^{1}$ & $\mathrm{~A} 1=\mathrm{NPK}(100 \%)$ & 5.00 & 1.64 & 3.12 \\
\hline Pine bark + organic matter $(1: 1)$ & $\mathrm{A} 2=\mathrm{N}$ and $\mathrm{K}(100 \%)+\mathrm{P}(150 \%)$ & 5.00 & 2.46 & 3.12 \\
\hline Wood shavings + organic matter $(1: 1)$ & $\mathrm{A} 2=\mathrm{N}$ and $\mathrm{K}(100 \%)+\mathrm{P}(150 \%)$ & 5.00 & 2.46 & 3.12 \\
\hline Grower $^{(1)}$ & $\mathrm{A} 2=\mathrm{N}$ and $\mathrm{K}(100 \%)+\mathrm{P}(150 \%)$ & 5.00 & 2.46 & 3.12 \\
\hline Pine bark + organic matter $(1: 1)$ & $\mathrm{A} 3=\mathrm{N}$ and $\mathrm{P}(100 \%)+\mathrm{K}(150 \%)$ & 5.00 & 1.64 & 4.70 \\
\hline Wood shavings + organic matter $(1: 1)$ & $\mathrm{A} 3=\mathrm{N}$ and $\mathrm{P}(100 \%)+\mathrm{K}(150 \%)$ & 5.00 & 1.64 & 4.70 \\
\hline Pine bark + organic matter $(1: 1)$ & $\mathrm{A} 3=\mathrm{N}$ and $\mathrm{P}(100 \%)+\mathrm{K}(150 \%)$ & 5.00 & 1.64 & 4.70 \\
\hline Wood shavings + organic matter $(1: 1)$ & $\mathrm{A} 4=\mathrm{N}(100 \%)+\mathrm{P}$ and $\mathrm{K}(150 \%)$ & 5.00 & 2.46 & 4.70 \\
\hline Grower $^{(1)}$ & $\mathrm{A} 4=\mathrm{N}(100 \%)+\mathrm{P}$ and $\mathrm{K}(150 \%)$ & 5.00 & 2.46 & 4.70 \\
\hline Pine bark + organic matter $(1: 1)$ & $\mathrm{A} 4=\mathrm{N}(100 \%)+\mathrm{P}$ and $\mathrm{K}(150 \%)$ & 5.00 & 2.46 & 4.70 \\
\hline Pine bark + organic matter $(1: 1)$ & A5 $=$ Grower $^{(1)}$ & 4.52 & 1.23 & 4.99 \\
\hline Wood shavings + organic matter $(1: 1)$ & A5 $=$ Grower $^{(1)}$ & 4.52 & 1.23 & 4.99 \\
\hline Grower $^{(1)}$ & A5 $=$ Grower $^{(1)}$ & 4.52 & 1.23 & 4.99 \\
\hline
\end{tabular}

${ }^{1}$ Growing media prepared with a mixture of $1 \mathrm{~m}^{3}$ of soil, $123 \mathrm{~L}$ of charcoal, $0.19 \mathrm{~m}^{3}$ of composted cow manure, $0.75 \mathrm{~kg}$ of lime and $1.7 \mathrm{~kg}$ of solid fertilizer 4-14-8 (meio de crescimento preparado com mistura de $1 \mathrm{~m}^{3}$ de solo, $123 \mathrm{~L}$ de carvão, $0,19 \mathrm{~m}^{3}$ de composto de esterco bovino, $0,75 \mathrm{~kg}$ de calcário e 1,7 kg de fertilizante sólido 4-14-8). 
The solutions A2, A3 and A4 contained $50 \%$ more phosphorus and potassium than the quantity recommended by Matthes et al. (1997). The level of nitrogen in the solutions was established in accordance with the recommendation of Matthes et al. (1997) and Tombolato et al. (2002), and kept constant in all fertigation treatments. The proportion of chloride, and the ratios $\mathrm{K}: \mathrm{Ca}=2.9$; $\mathrm{Ca}: \mathrm{Mg}=2.5 ; \mathrm{S}: \mathrm{Mg}=2$ and $\mathrm{Ca}: \mathrm{S}=$ 1.25 were established according to the recommendation of Tombolato et al. (2002). Electrical conductivity (CE) in nutritive solutions was maintained between 1.1 and $1.5 \mathrm{dS} \mathrm{cm}^{-1}$, following the recommendation for the cultivation of anthurium (Talia et al., 2003; Dufour \& Guérin, 2003). The micronutrients were applied every two weeks by foliar spraying with Supatrace ${ }^{\mathrm{TM}}(3.2 \% \mathrm{~N}+$ $4.6 \% \mathrm{~S}+0.8 \% \mathrm{~B}+1 \% \mathrm{Cu}+3.2 \% \mathrm{Fe}$ $+2.4 \% \mathrm{Mn}+0.04 \% \mathrm{Mo}+3.0 \% \mathrm{Zn}$ $\mathrm{p} / \mathrm{v}$ ) at a dose of 150 milliliters per 100 $\mathrm{L}$ of water, with a volume of spray of $500 \mathrm{~L} / \mathrm{ha}$.

The nutritive fertigation solutions (A1 to A4) were compared with the fertilization usually applied by the grower (A5) (Table 3). This was applied 30, 60 and 90 days after transplanting with granulated slow releasing fertilizer with a formulation of 12:11:18 in an amount of $49 \mathrm{~g} \mathrm{~m}^{-2}$. At 120, 150 and 180 days after transplanting, solid fertilizer with a formulation of 12-11-18 in a quantity of $60 \mathrm{~g} \mathrm{~m}^{-2}$ was applied, and at 210 and 240 days after transplanting, solid fertilizer with a formulation of 15-00-15 in a quantity of $50 \mathrm{~g} \mathrm{~m}^{-2}$ was applied, complemented by $20 \mathrm{~g} \mathrm{~m}^{-2}$ of Gafsa superphosphate.

Yield and flower quality were evaluated weekly starting at two months after transplanting and for the subsequent nine months. In such evaluation the number of flowers harvested per plant, the length of the spathe, the length of the floral stem were measured, and product classification was performed as recommended by Ibraflor (2000) in Extra, Class I, and Class II. The product was also analyzed for the presence of defects in the spathe caused by insects, mechanical damage, blemishes, and deformation in the spathe.

Treatments were distributed into blocks under subdivided plots, where the fertilization was established in the plot, and the growing media in the subplot, with three repetitions of 20 plants per treatment. Statistical analysis was performed with the program MSTAT, analysis of variance was performed with the F-Test, and comparison of means by the Tukey test.

\section{RESULTS AND DISCUSSION}

Yield, quantified by the mean number of flowers per plant, did not differ between the three growing media or between the five fertilizations tested (Table 4). This concurs with results of a study conducted by Henny (1999) who observed that in anthurium plants, grown in Osmocote (Sierra Chemical Company, Milpitas, CA), given three doses of nitrogen $(52.5,70.0$ and 88.0 $\mathrm{kg} \mathrm{ha}^{-1}$ year $\left.^{-1}\right)$, the number of buds and open flowers were not significantly affected by the nutrition. Dufour \& Clairon (1997), studying anthurium soilless growth with concentrations of $\mathrm{N}$ of $2.8 \mathrm{mg} / \mathrm{L}$ and $\mathrm{P}$ of $39.9 \mathrm{mg} / \mathrm{L}$, or $\mathrm{N}$ from 7.84 to $18.62 \mathrm{mg} / \mathrm{L}$, and $\mathrm{K}^{+}$from 5.46 to $207.48 \mathrm{mg} / \mathrm{L}$ did not observe a significant effect on number of flowers in anthurium. Higaki \& Poole (1978), growing anthurium in various organic substrates, such as sugarcane bagasse and wood shaving, concluded that during the first and second years of cultivation, the levels of fertilizers equivalent to one, two and three times the levels of 448-196-370 $\mathrm{kg}$ NPK ha- year $^{-1}$ did not influence the production of anthurium flowers. According to Dufour \& Guérin (2003), floral differentiation in anthurium begins very early, and the terminal meristem is already differentiated when the anterior flower emerges. Floral initiation begins approximately 90 days before emergence, indicating that each flower begins its growth almost 50 days before the anterior flower is harvested. According to Talia et al. (2003), Cuquel \& Grossi (2004), and Singh et al. (2011), anthurium yield varies from 4.3 to 9.4 flowers per plant per year. This means that a new flower appears every 39 to 84 days. This characteristic may have played a role in the response to fertilization not having been immediate, especially since it was the first year of cultivation, when the plant had still not expressed all its production potential.

The results obtained demonstrated that the growing media utilized affected the quality of anthurium flowers (Table $4)$. In the growing media wood shavings + organic matter (1:1), the biggest length of spathes was produced (Table 5). This finding is in agreement with Singh et al. (2011) who observed that growing media significantly affects the size of anthurium flowers.

The length of the floral stem did not differ with the three different growing media, or between the five fertilizations utilized (Table 4). This finding concurs with those of Higaki \& Poole (1978), who observed that fertilization did not affect the length of the anthurium floral stem, in the first year of growth. In the same study, in the second and third years, the fertilization treatment of two times the recommended level produced flowers with greater stem length, but not being economically viable. There is also concordance with Devecchi \& Remoti (2003), who studied calla (Zantedeschia aethiopica) in which different doses of nitrogen and potassium did not significantly affect length of floral stem.

In regard to commercial classification of anthurium flowers it was affected by the interaction of fertilization utilized and the growing media used (Table 4). The biggest length of spathes, which is one of the anthurium quality parameters (Ibraflor, 2000), was observed with all fertilizers applied in flowers that came from plants cultivated in growing media prepared with wood shavings + organic compost (1:1) (Table 5). Well aerated (Caldari-Junior, 2004) without compaction, with good porosity, and with good capacity to store water without compromising the substrate aeration (Sakai, 2004) are desirable features of anthurium growing medias. The highest initial porosity of the wood shavings + organic compost (1:1) (Table 2), more than $85 \%$ (Minami \& Salvador, 2010), could have contributed to the better quality of flowers cultivated in this growing media. Caldari-Junior (2004) agrees with this supposition reporting that porosity is one of the 
Table 4. Mean values of yield and characteristics of $A$. andraeanum flowers grown with different growing media and fertilizations (valores médios de produtividade e características de flores de $A$. andraeanum cultivadas em diferentes meios de cultura e fertilizantes). Guaratuba, UFPR, 2004-2005.

\begin{tabular}{|c|c|c|c|c|c|c|c|}
\hline Fertilization & Growing media & $\begin{array}{l}\text { Flowers/ } \\
\text { plant }\left(\mathbf{n}^{0}\right)\end{array}$ & $\begin{array}{l}\text { Lenght of } \\
\text { spathe }(\mathrm{cm})\end{array}$ & $\begin{array}{l}\text { Lenght of floral } \\
\text { stem }(\mathrm{cm})\end{array}$ & $\begin{array}{c}\text { Extra } \\
\text { flowers }\left(n^{0}\right)\end{array}$ & $\begin{array}{c}\text { Class I } \\
\text { flowers }\left(n^{0}\right)\end{array}$ & $\begin{array}{c}\text { Class II } \\
\text { flowers }\left(n^{0}\right)\end{array}$ \\
\hline \multirow{3}{*}{ A1 } & $\begin{array}{l}\text { Pine bark }+ \text { organic } \\
\text { matter }(1: 1)\end{array}$ & 3.45 & 11.50 & 52.27 & 2.45 & 0.38 & 0.62 \\
\hline & $\begin{array}{l}\text { Wood shavings }+ \\
\text { organic matter }(1: 1)\end{array}$ & 3.72 & 11.62 & 53.34 & 2.83 & 0.50 & 0.39 \\
\hline & Grower $^{1}$ & 3.50 & 11.39 & 53.54 & 2.11 & 0.72 & 0.67 \\
\hline \multirow{3}{*}{ A2 } & $\begin{array}{l}\text { Pine bark }+ \text { organic } \\
\text { matter }(1: 1)\end{array}$ & 3.61 & 11.05 & 50.80 & 2.27 & 0.89 & 0.45 \\
\hline & $\begin{array}{l}\text { Wood shavings }+ \\
\text { organic matter }(1: 1)\end{array}$ & 3.67 & 11.39 & 52.54 & 2.94 & 0.22 & 0.51 \\
\hline & Grower $^{1}$ & 3.28 & 10.46 & 49.10 & 2.11 & 0.67 & 0.50 \\
\hline \multirow{3}{*}{ A3 } & $\begin{array}{l}\text { Pine bark }+ \text { organic } \\
\text { matter }(1: 1)\end{array}$ & 3.72 & 10.96 & 49.14 & 2.16 & 1.00 & 0.56 \\
\hline & $\begin{array}{l}\text { Wood shavings }+ \\
\text { organic matter }(1: 1)\end{array}$ & 3.28 & 11.43 & 51.17 & 2.22 & 0.61 & 0.45 \\
\hline & Grower $^{1}$ & 3.50 & 11.25 & 52.30 & 2.50 & 0.62 & 0.34 \\
\hline \multirow{3}{*}{ A4 } & $\begin{array}{l}\text { Pine bark }+ \text { organic } \\
\text { matter }(1: 1)\end{array}$ & 3.78 & 11.80 & 54.54 & 2.78 & 0.67 & 0.33 \\
\hline & $\begin{array}{l}\text { Wood shavings }+ \\
\text { organic matter }(1: 1)\end{array}$ & 3.50 & 11.64 & 54.00 & 2.83 & 0.50 & 0.17 \\
\hline & Grower ${ }^{1}$ & 3.06 & 11.35 & 51.74 & 2.06 & 0.50 & 0.50 \\
\hline \multirow{3}{*}{ A5 } & $\begin{array}{l}\text { Pine bark }+ \text { organic } \\
\text { matter }(1: 1)\end{array}$ & 3.34 & 10.22 & 43.64 & 1.56 & 0.94 & 0.84 \\
\hline & $\begin{array}{l}\text { Wood shavings }+ \\
\text { organic matter }(1: 1)\end{array}$ & 3.72 & 11.89 & 52.17 & 2.39 & 0.89 & 0.44 \\
\hline & Grower $^{1}$ & 3.17 & 10.94 & 44.94 & 2.06 & 0.67 & 0.44 \\
\hline \multicolumn{8}{|c|}{ Significance by F test } \\
\hline \multicolumn{2}{|l|}{ Fertilizations } & ns & ns & & ns & ns & ns \\
\hline \multicolumn{2}{|c|}{ Growing media } & ns & $*$ & ns & $* *$ & $*$ & ns \\
\hline \multicolumn{2}{|c|}{$\begin{array}{l}\text { Interaction between fertilizers and } \\
\text { growing media }\end{array}$} & ns & ns & ns & $*$ & $*$ & ns \\
\hline \multicolumn{2}{|l|}{ Fertilizations } & ns & ns & ns & ns & ns & ns \\
\hline
\end{tabular}

${ }^{1}$ Growing media prepared with a mixture of $1 \mathrm{~m}^{3}$ of soil, $123 \mathrm{~L}$ of charcoal, $0.19 \mathrm{~m}^{3}$ of composted cow manure, $0.75 \mathrm{~kg}$ of lime and $1.7 \mathrm{~kg}$ of solid fertilizer 4-14-8 (meio de crescimento preparado com mistura de $1 \mathrm{~m}^{3}$ de solo, $123 \mathrm{~L}$ de carvão, $0,19 \mathrm{~m}^{3}$ de composto de esterco bovino, $0,75 \mathrm{~kg}$ de calcário e $1,7 \mathrm{~kg}$ de fertilizante sólido 4-14-8); *Significance at 5\% probability; ns= no significance (significativo a 5\%

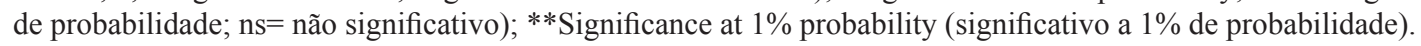

growing media features to be prioritized in the choice of the raw material. The wood shavings + organic matter (1:1) growing media and the pine bark + organic matter $(1: 1)$ growing medias showed better performance than the grower media probably because of their lower dry density (Table 2). Additionally the higher easily available water and the higher buffering capacity water might have favored wood shavings + organic compost (1:1) (Table 2) better performance.

Although there are reports in the literature that fertilization affects the incidence of diseases (Sholberg \& Conway, 2004) and of physiologic disturbances (Paull et al., 1992), occurring in post-harvest, the number of Class II flowers was shown to be independent of fertilization and of growing media utilized (Table 4).

The present work allowed to conclude that the growing media utilized enhanced the commercial quality of the flowers. Best flowers were produced in plants grown in the growing media prepared with wood shavings + organic compost (1:1) with all fertilization tested. 
Table 5. Characteristics of $A$. andraeanum flowers grown with different growing media and fertilizations (características de flores de $A$. andreanum cultivadas com diferentes meios de cultura e fertilizantes). Guaratuba, UFPR, 2004-2005.

\begin{tabular}{|c|c|c|c|}
\hline & Growing media & \multicolumn{2}{|c|}{ Mean length of spathes $(\mathrm{cm})$} \\
\hline & Pine bark + organic matter $(1: 1)$ & \multicolumn{2}{|c|}{$11.11 \mathrm{~B}$} \\
\hline & Wood shavings + organic matter $(1: 1)$ & \multicolumn{2}{|c|}{$11.63 \mathrm{~A}$} \\
\hline & Grower $^{2}$ & \multicolumn{2}{|c|}{$11.07 \mathrm{~B}$} \\
\hline Fertilization & Growing media & $\begin{array}{l}\text { Extra flowers } \\
\left(\text { mean } \mathbf{n}^{0}\right)\end{array}$ & $\begin{array}{l}\text { Class I flowers } \\
\left(\text { mean } \mathbf{n}^{0}\right)\end{array}$ \\
\hline \multirow{3}{*}{ A1 } & Pine bark + organic matter $(1: 1)$ & $2.45 \mathrm{AB}$ & $0.38 \mathrm{~A}$ \\
\hline & Wood shavings + organic matter $(1: 1)$ & $2.83 \mathrm{~A}$ & $0.50 \mathrm{~A}$ \\
\hline & Grower $^{2}$ & $2.11 \mathrm{~B}$ & $0.72 \mathrm{~A}$ \\
\hline \multirow{3}{*}{ A2 } & Pine bark + organic matter $(1: 1)$ & $2.27 \mathrm{AB}$ & $0.89 \mathrm{~A}$ \\
\hline & Wood shavings + organic matter $(1: 1)$ & $2.94 \mathrm{~A}$ & $0.22 \mathrm{~B}$ \\
\hline & Grower $^{2}$ & $2.11 \mathrm{~B}$ & $0.67 \mathrm{~A}$ \\
\hline \multirow{3}{*}{ A3 } & Pine bark + organic matter $(1: 1)$ & $2.17 \mathrm{~A}$ & $1.00 \mathrm{~A}$ \\
\hline & Wood shavings + organic matter $(1: 1)$ & $2.22 \mathrm{~A}$ & $0.61 \mathrm{~A}$ \\
\hline & Grower $^{2}$ & $2.50 \mathrm{~A}$ & $0.62 \mathrm{~A}$ \\
\hline \multirow{3}{*}{ A4 } & Pine bark + organic matter $(1: 1)$ & $2.78 \mathrm{~A}$ & $0.67 \mathrm{~A}$ \\
\hline & Wood shavings + organic matter $(1: 1)$ & $2.83 \mathrm{~A}$ & $0.50 \mathrm{~A}$ \\
\hline & Grower $^{2}$ & $2.06 \mathrm{~B}$ & $0.50 \mathrm{~A}$ \\
\hline \multirow{3}{*}{ A5 } & Pine bark + organic matter $(1: 1)$ & $1.56 \mathrm{~B}$ & $0.94 \mathrm{~A}$ \\
\hline & Wood shavings + organic matter $(1: 1)$ & $2.39 \mathrm{~A}$ & $0.89 \mathrm{~A}$ \\
\hline & Grower $^{2}$ & $2.06 \mathrm{AB}$ & $0.67 \mathrm{~A}$ \\
\hline
\end{tabular}

${ }^{1}$ Means followed by same letter in column within each fertilization did not differ by Tukey's test $(\alpha=0.05)$ (médias seguidas por letras iguais na coluna entre cada fertilização, não diferem pelo teste de Tukey $(\alpha=0,05))$; ${ }^{2}$ Growing media composed of a mixture of $1 \mathrm{~m}^{3}$ of soil. 123 L of charcoal. $0.19 \mathrm{~m}^{3}$ of composted cow manure. $0.75 \mathrm{~kg}$ of lime and $1.7 \mathrm{~kg}$ of solid fertilizer 4-14-8 (meio de crescimento preparado com mistura de $1 \mathrm{~m}^{3}$ de solo, $123 \mathrm{~L}$ de carvão, $0,19 \mathrm{~m}^{3}$ de composto de esterco bovino, 0,75 kg de calcário e 1,7 kg de fertilizante sólido 4-14-8).

\section{REFERENCES}

CALDARI-JUNIOR P. 2004. Técnicas de cultivo do antúrio (Anthurium andraeanum). Revista Brasileira de Horticultura Ornamental 10: 42-44.

CBI MARKET INFORMATION DATABASE. 2007. Available at http:// www.cbi.eu. Accessed on August 10 2009.

CHANG KH; WU RY; CHUANG KC; HSIEH TF; CHUNG RS. 2010. Effects of chemical and organic fertilizers on the growth, flower quality and nutrient uptake of Anthurium andreanum, cultivated for cut flower production. Scientia Horticulturae 125: 434-441.

CUQUEL FL; GROSSI ML. 2004. Produção de antúrio no litoral do Estado do Paraná. Revista Brasileira de Horticultura Ornamental 10: 35-37.

DESHMUKH HV; MEHETREP B. 2010. Effect of different nitrogen sources on growth and sporulation of Colletotrichum gloeosporioides causing anthracnose disease of Anthurium. International Journal of Plant Protection 3: 327-328.

DEVECCHI M; REMOTI D. 2003. Influence of fertilization on vegetative growth and flowering of the calla (Zantedeschia aethiopica Spreng). Acta Horticulturae 614: 541-545.

DUFOUR L; CLAIRON M. 1997. Advances in fertilization of anthurium hybrids in Guadaloupe (FWI). Acta Horticulturae 450: 433-437.

DUFOUR L; GUÉRIN V. 2003. Growth, developmental features and flower production of Anthurium andreanum Lind. in tropical conditions. Scientia Horticulturae 98: 25-35.

DUFOUR L; GUÉRIN V. 2005. Nutrient solution effects on the development and yield of Anthurium andreanum Lind. in tropical soilless conditions. Scientia Horticulturae 105: 269-282.

FERMINO MH. 2003. Métodos de análise para caracterização física de substratos para plantas. Porto Alegre: UFRGS. 104p. (Tese doutorado).

HENNY RJ. 1999. "Red Hot" Anthurium. HortScience 34: 153-154.

HIGAKI T; POOLE R. 1978. A media and fertilizer study in anthurium. Journal of American Society for Horticultural Science 103: 98-100.

HORWITZ W; LATIMER-JUNIOR GW. (ed). 2011. Official methods of analysis of AOAC International.18. ed., 4. rev. Gaithersburg,
AOAC International.

IBRAFLOR. Padrão IBRAFLOR de qualidade. 2000, 87p.

LOGES V; CASTRO ACR; TEIXEIRA MCF; CASTRO MFA. 2004. Experiências de cultivo de antúrio para flor de corte em Pernambuco. Revista Brasileira de Horticultura Ornamental 10: 38-41.

MATTHES LAF; CASTRO CEF; TOMBOLATO AFC; FEITOSA CT. 1997. ANTÚRIO. IN: RAIJ BV; CANTARELLA H; QUAGGIO JA; FURLANI AMC Recomendações de adubação e calagem para o Estado de São Paulo. 2. ed. Ver. Atual. Campinas, Instituto Agronômico/Fundação IAC, 285p. (Boletim Técnico, 100).

MINAMI K.; SALVADOR ED. 2010. Substrato para plantas. Piracicaba. Degaspari. 226p.

PAULL RE; HIGAKI T; IMAMURA JS. 1992. Season and fertilization affect the postharvest flower life of anthurium. Scientia Horticulturae 125-134.

PFLEGER FL; GOULD SL. 2009. Bacterial leaf diseases of foliage plants. WW-01170. University of Minnesota. College of Agriculture, Food and Environmental Science. Available at: http://www.extension.umn. edu/distribution/horticulture/dg1170.html. 
Accessed on September $2^{\text {nd }} 2009$.

SAKAI E. 2004. Cultivo de antúrio: uma experiência no Vale do Ribeira. Revista Brasileira de Horticultura Ornamental 10: 27-34.

SHOLBERG PL; CONWAY WS. 2004. Postharvest Pathology. In: Gross, KC; Wang $\mathrm{CY}$; Saltveit M. The commercial storage of fruits, vegetables, and florist and nursery stocks. USDA, ARS: Agricultural Handbook, 66, 130p.

SINGH P; DHADUK BK; CHAWLA SL.
2011. Standardization of growing medium for anthurium cv. Flame under protected conditions. Indian Journal of Horticulture 68: 86-90.

STANCATO GC; SILVEIRA APD. 2010. Micorrização e adubação de mudas micropropagadas de antúrio, cv. Eidibel: crescimento e aclimatização ex vitro. Bragantia 69: 957-963.

TALIA MAC; CRISTIANO G; FORLEO LR. 2003. Evaluation of new anthurium cultivars in soilles culture. Acta Horticulturae 614:
223-226

TOMBOLATO AFC; RIVAS EB; COUTINHO LN; BERMANN EC; IMENES SDL; FURLANI PR; CASTRO CEF; MATTHES LAF; SAES LA; COSTA AMM; DIASTAGLIACOZZO GM; LEME JM. 2002. $O$ cultivo de antúrio: produção comercial. Campinas: Instituto Agronômico, $47 \mathrm{p}$.

UMAHARAN P; ELIBOX W. The UWI St. Augustine Anthurium Web Site: Horticultural Management, 2011 Available at http://sta.uwi. edu/anthurium/horticulturalManagement.asp. Accessed on January $28^{\text {th }} 2011$. 